УДОСКОНАЛЕННЯ ПРОФЕСІЙНОӤ ПІДГОТОВКИ МАЙБУТНІХ ФАХІВЦІВ 3 ЕКОНОМІКИ В УКРАЇНІ НА ОСНОВІ ДОСВІДУ РЕСПУБЛІКИ ПОЛЬЩА

\title{
DEVELOPMENT OF PROFESSIONAL TRAINING OF FUTURE ECONOMISTS IN UKRAINE ON THE BASIS OF POLAND EXPERIENCE
}

\begin{abstract}
У роботі проаналізовано підгрунтя національної економічної освіти, схарактеризовано засади національної економічної освіти в закладах вищої освіти, стисло окреслено їі сучасні вимоги, недоліки, надано пропозиціі на основі позитивного досвіду Республіки Польщі. Завдання статmі полягають в аналізі сучасної економічної освіти в Україні; відображенні позитивного досвіду підготовки економістів у Польщі; визначенні можливості впровадження позитивного досвіду вищої економічної освіти Польщі в українські вищі навчальні заклади з урахуванням сучасних змін. Матеріалом роботи $\epsilon$ дослідження українських і польських учених щодо економічної освіти в Україні та Польщі. Аналізуються вихідні позиції національної економічної освіти, описуються основи національної економічної освіти у вищих навчальних закладах, а також сучасні вимоги економічної освіти, її недоліки, пропозиції, коротко окреслено позитивний досвід на базі Польщі. Обірунтовано висновок, що майбутня підготовка економістів - че складний процес співпраці викладачів і студентів, який характеризується постійними трансорормаціями й оновленням змісту викладання відповідно до змін у сучасному економічному світі. Особливістю польської економічної освіти є те, що програми навчання насичені дисциплінами, які дають знання та навички практичного вирішення економічних завдань, такими як економетрія, статистика, економічне програмування, методи оптимізації, стратегічне планування і прогнозування. Високий рівень спеціалізації та прооресії $є$ характеристикою навчальних програм майбутнього економіста у вищих навчальних закладах. Зміст вищої економічної освіти в Польщі базується на стандартах, що регулюють тематичні модулі курсів і нормативні професійні та кваліфрікаційні описи з кожного предмета. У навчальному процесі в Польщі існують різні методи, фоорми, підходи, засоби майбутнього навчання економістів. Цей досвід корисний Україні.
\end{abstract}

УДК 377

2019-19-1-7

Беньковська Н.Б.,

канд. пед. наук, доцент

Одеського торговельно-економічного

інституту

Київського національного

торговельно-економічного університету
Ключові слова: освіта, економісти, професійна підготовка, заклад вищої освіти, досвід, Україна, Республіка Польща.

The basic principles of development the economic education in Ukraine on the basis of Poland experience are offered in the article. The aim of the article is to show the economic education development in Ukraine on the basis of Poland experience. The tasks of the article consist of the analysis of the modern economic education in Ukraine; reflection the positive experience in training economists in Poland; determination the possibility of introduction positive experience of higher economic education in Poland to the Ukrainian high educational establishments taking into account the modern changes. The material of the work is the research of the Ukrainian and Polish scientists as for the economic education in Ukraine and Poland. As a result of the research the initial positions of national economic education are analyzed in the work, the bases of national economic education in high educational establishments are described, as well as modern requirements of economic education, its disadvantages, suggestions on the basis of Poland positive experience are briefly outlined. We conclude that future economist training is the difficult process of lecturers' and students' co-operation, which is characterized by permanent transformations and updates the maintenance in teaching according to the changes in modern economic world. The high level of specialization and profession is the characteristic of training programs of future economist in high educational establishments. The content of higher economic education in Poland is based on the standards which regulate the thematic modules of courses and normative professional and qualifying descriptions on every subject. In the educational process in Poland there are various methods, forms, approaches, and means of future economist training. This experience is useful to Ukraine. Key words: education, economists, professional preparation, high educational establishments, experience, Ukraine, Poland.
Постановка проблеми в загальному вигляді. Основні проблеми професійної підготовки майбутніх фрахівців економічного профрілю - визначення загальнотеоретичних підходів до вирішення нагальних проблем навчання економістів. Підготовка майбутніх фрахівців економічного профрілю пов'язана з потребою й попитом економіки. Тому вивчення досвіду країн із високим рівнем економічного розвитку, таких як Республіка Польща, $€$ дуже корисним для України. Система освіти в Польщі за останні десять років стрибнула набагато вперед і продовжує активно розвиватися й понині. При цьому підвищується не лише чисельність навчально-освітніх закладів, а і якість викладання в них.
Усебічна реформа в Польщі розпочалася наприкінці 90-х рр. XX ст., охопила всі ланки системи освіти - її структуру, зміст, управління, фрінансування, підготовку фрахівців різних напрямів. Стратегією реформи освіти в Польщі є створення принципово нової системи освіти, яка б давала можливість кожній людині отримати й постійно поповнювати знання протягом усього її активного життя, - системи неперервної освіти.

Економічна освіта - це вид діяльності, що передбачає фрормування економічних знань, умінь і навичок господарювання, засвоєння досвіду розвитку соціально-економічного середовища в процесі підготовки фрахівців для економічних служб, підприємств і спеціальних економічних організа- 
цій. У такому контексті економічна освіта являє собою систему освітніх закладів, організацій і підприємств, які здійснюють переважно освітню діяльність, спрямовану на задоволення потреб населення в освітніх послугах і підготовку кваліфрікованих працівників. Економічна освіта має власну структуру та характеристики, впливає на особистісні якості людини шляхом фрормування економічного мислення й економічної грамотності, а тому слугує підвищенню національної економічної культури.

Аналіз останніх досліджень і публікацій свідчить про те, що у вітчизняній теорії і практиці освіти існують підходи, близькі до сучасних зарубіжних концепцій. Значний інтерес становлять наукові праці з питань профресійної підготовки фрахівців у контексті суспільних закордонних трансорормацій (В. Андрущенко, М. Євтух, І. Зязюн, О. Капітанець, В. Кремень, Н. Ничкало та ін.). Зміст економічної підготовки фрахівців економічної галузі за кордоном розглядали А. Загородня, М. Романюк, $€$. Савельєв, В. Свистун, Н. Беньковська.

Виділення не вирішених раніше частин загальної проблеми. Але варто констатувати, що в українській науковій літературі ще не проведено всебічного аналізу використання позитивного досвіду підготовки майбутніх економістів в системі вищої освіти Польщі для України.

Метою статті $€$ визначення основних засад удосконалення економічної освіти в Україні на основі досвіду Республіки Польщі, аналіз сучасного стану економічної освіти в Україні;

Завдання статті полягають у такому:

- дослідженні позитивного досвіду підготовки економістів у Республіці Польщі;

- визначенні можливості впровадження позитивного досвіду вищої економічної освіти в Республіці Польщі для українських закладів вищої освіти з урахуванням змін на сучасному етапі.

Для розв'язання окреслених завдань і досягнення мети використано такі методи: аналіз, синтез, порівняння, узагальнення (для вивчення та узагальнення наукової літератури 3 конкретнонаукової методології проблеми, проведення категоріального аналізу базових понять та окреслення взаємозв'язку між ними).

Виклад основного матеріалу. У Концепції розвитку економічної освіти в Україні (2003) зазначено, що її головне завдання - поширення й використання економічних знань для фрормування творчої особистості, підвищення якості життя українського народу та прогресивного розвитку суспільства. Виходячи із цього, метою розвитку системи економічної совіти $€$ інтенсивне накопичення соціально-економічних знань та оптимізація їх використання як головного потенціалу необмеженого ресурсу розвитку українського суспільства та його соціально-орієнтованої економіки. Розви- ток економічної освіти ґрунтується на принципах, визначених Законами України «Про освіту» (1991) та «Про вищу освіту» (2002), таких як суспільна корисність економічних знань; соціальна справедливість, толерантність, суспільна злагода й партнерство всіх учасників економічної освітньої діяльності; гуманізм, демократичність, відкритість і доступність економічної освіти; соціальна обґрунтованість економічного мислення в кожній сорері профресійної діяльності; поєднання фрундаментальності й фаховості різноманітних освітніх програм, основаних на індивідуалізації підготовки економічних кадрів відповідно до попиту на ринку праці; безперервність, системність і систематичність, інноваційність змісту економічної освіти; відповідність якості освітніх послуг потребам особи, соціальних і професійних груп країни й іноземних громадян; адаптація світового досвіду та збереження кращих вітчизняних освітян, традицій, розширення міжнародного співробітництва; державна підтримка підготовки фрахівців; інтеграція економічної освіти і наукових досліджень. Вона охоплює чотири блоки дисциплін, що формують сучасний світогляд і зумовлюють потребу в постійному оновленні економічних знань, умінь, навичок: загальноосвітніх, фундаментальних, інноваційнопрактичних і дисциплін спеціальної підготовки. Дисципліни, включені в названі блоки, забезпечують комплексне багатоаспектне вивчення закономірностей економічної сфери суспільства [2].

Нині йдуть процеси трансформації системи економічної освіти в напрямі розширення іії багаторівневості.

Профресійна підготовка сучасних економістів передбачає розуміння ними закономірностей формування й розвитку відтворювальних процесів на макро- й мікрорівнях у взаємозв'язку з розвитком політичних, культурних та інших суспільних процесів. Один із ключових напрямів розвитку економічної освіти - підвищення якості навчання через упровадження в процес підготовки активних методів навчання (ділові, рольові ігри, семінари-дискусії, колоквіуми, ситуаційні вправи); розроблення сучасних дистанційних технологій навчання із застосуванням комп'ютерних мереж; створення системи узагальнення та поширення досвіду використання сучасних методик навчання; сприяння інфрорматизації навчального процесу. 3 економічною освітою безпосередньо пов'язана економіка освіти, що вивчає місце й роль системи освіти в економіці, організаційно-економічний механізм фрункціонування освіти, фрінансування освітньої діяльності та соціально-економічну ефективність освітньої діяльності для суспільства.

В Україні на ринку освітніх послуг у сорері економічної освіти нині спостерігається конкуренція. Процеси приватизації системи вищої освіти дали змогу створити мережу недержавних закладів 
вищої освіти, які останніми роками запровадили багато інноваційних управлінських рішень, нових освітніх технологій в економічну освіту. Формування середнього класу та зменшення рівня безробіття спричиняють зростання попиту на економічну освіту на комерційній основі й відповідне збільшення контингенту студентів. Прогнози стосовно того, що економісти в найближчому майбутньому не будуть затребувані на ринку праці, не виправдані. Аналіз стану української системи економічної освіти засвідчує їі високий потенціал розвитку, підтверджений задовільними тенденціями зміни багатьох характеристик.

Разом із тим у системі економічної освіти останніми роками постала низка проблем, багато з яких $€$ об'єктивним відображенням глобальних процесів переходу країни в постіндустріальний стан.

Основні динамічні трансорормаційні процеси, які відбуваються на ринку економічної освіти сьогодення, якісно змінюють фрункцію та роль системи стратегічного управління економічної освіти, a came:

- посилення міжнародної інтеграції та приєднання України до Болонської конвенції;

- збільшення кількості недержавних закладів вищої освіти;

- фрормування попиту і пропозиції освітніх послуг з урахуванням вимог ринку праці;

- посилення конкуренції у зв'язку з несприятливими демографрічними фракторами.

Сучасні професійно-економічні знання населення забезпечують подолання соціальних проблем (насамперед безробіття). Із цих позицій актуальним завданням державної політики стає зміна вимог до освіти, які з погляду економічної освіти полягають у тому, щоб дати якісно новий рівень знань та оновлювати їх протягом усього періоду трудової діяльності.

Так, в Україні поступово впроваджуються зміни, що сприяють удосконаленню професійної підготовки економістів. На наше глибоке переконання, до цього необхідно додати врахування позитивного досвіду Республіки Польщі.

Зміст професійної підготовки фрахівців економічної галузі в Польщі визначається освітніми стандартами для галузі дослідження, зокрема економіки [3].

Цей освітній стандарт передбачає підготовку орахівців за двома ступенями (циклами).

Підготовка фрахівців першого циклу триває не менш ніж 6 семестрів. Кількість годин, відведених на вивчення навчальних предметів, не повинна бути меншою за 1800. ECTS (європейська система накопичення кредитів) повинна бути не меншою за 180 кредитів.

Підготовка фрахівців другого циклу триває не менше ніж 4 семестри. Кількість годин, відведених на вивчення навчальних предметів, не повинна бути меншою за 800. Кількість кредитів не повинна бути меншою за 120.

Позитивною особливістю польської системи підготовки економістів є ґрунтовна теоретична й науково-методична база програм навчання. Для розвитку практичних навичок студенти виконують проекти за замовленням фрірм під керівництвом університетських консультантів. Професори університетів можуть також надавати платні консалтингові послуги бізнесменам.

Високу популярність останнім часом у практиці навчання економістів у Республіці Польщі завоювали активні методи навчання - ділові ігри, тренінги та ситуаційні завдання, так звані «case studies». Ситуаційні завдання моделюють реальну практичну ситуацію на конкретному підприємстві в тій чи іншій галузі. Вирішення таких завдань дає студентам змогу застосувати на практиці отримані в ході навчання теоретичні знання, проявити творчі здібності, гнучкість розуму та лідерські особисті якості, а також психологічно підготуватися до практичної управлінської діяльності на підприємстві.

Польська система підготовки економічних кадрів орієнтована на випуск економіста-практика, особистість, здатну вирішувати різноманітні ділові завдання та гнучко реагувати на мінливі економічні умови, тоді як заклади вищої освіти України готують більшою мірою теоретиків, які володіють знаннями про світові економічні системи й азами мікроекономіки, але при цьому важко орієнтуються у вирішенні конкретних практичних завдань і не здатні самостійно приймати нестандартні рішення.

На нашу думку, необхідно переглянути навчальні програми економічних спеціальностей у вітчизняній вищій школі, щоб збільшити частку активних методів, фрорм, прийомів, засобів навчання.

У Республіці Польщі останніми роками заклади вищої освіти впроваджують принцип випереджаючого навчання, коли на лекціях розглядаються новітні досягнення в тій чи іншій галузі, причому ці досягнення можуть бути ще не висвітлені в пресі. Такий педагогічний прийом сприяє підвищенню зацікавленості студентів, а також стимулюванню активної пізнавальної діяльності.

Велика увага також приділяється фрормуванню навичок самостійного навчання, аналізу.

Позитивною особливістю польської економічної освіти є, на наш погляд, також і те, що програми навчання насичені дисциплінами, які дають знання та навички практичного вирішення економічних завдань, такими як економетрія, статистика, економічне програмування, методи оптимізації, стратегічне планування і прогнозування. Програми навчання економічних кадрів у вітчизняній вищій школі містять більшу кількість курсів, що дають узагальнені, теоретизовані знання (напри- 
клад, «Основи економіки», «Маркетинг», «Біржова справа», «Банківська справа» тощо).

Зміст профресійної підготовки фрахівців у університетах економіки в Республіці Польщі також залежить і від різних типів фракультетів, що, на нашу думку, є доречним. Так, Індивідуальний фракультет (університет економіки в Кракові) запроваджено як альтернативний напрям професійної підготовки на фракультеті економіки й міжнародних відносин, який повинен стати основним складником персоналізованої освіти, зорієнтованої на конкретні потреби та очікування студентів. Студент зможе вибрати свої спеціальні предмети, які дають йому змогу визначити індивідуальний шлях подальшої освіти й особистісного розвитку. Це рішення буде фрормувати їхній професійний профріль [4]

Система підготовки фрахівців передбачає наявність викладача-тьютора та студента-учня. Викладачами-тьюторами $є$ сертифіковані викладачі. Викладач-тьютор - це людина, яка виступає як консультант, захисник індивідуальних науковопошукових проектів студентів. Це допомагає у виборі об'єктів і напрямів подальшої спеціалізації. Завдяки систематичним зустрічам викладач вивчає інтереси окремого студента.

Репетитор допомагає студенту у виборі предметів, навчальних програм і методів їх реалізації; аналізує запропонований студентом індивідуальний навчальний план поточного семестру, затверджує в кінці навчального року картки, що містять перелік завершених студентських заходів, кількість отриманих кредитів і пропозиції щодо заохочення та продовження дослідження [1].
Висновки. Отже, аналіз змісту професійної підготовки майбутніх фрахівців 3 економіки в Польщі дає можливість стверджувати, що змісти навчальних курсів, які студенти вивчають у межах освітніх програм, кращою мірою сприяють фрормуванню профресійних та особистісних якостей, тоді як заклади вищої освіти України обмежені у виборі таких навчальних курсів у межах освітніх програм.

Позитивним досвідом для України є те, що процеси приватизації системи вищої освіти дали змогу створити мережу недержавних закладів вищої освіти, які останніми роками запровадили багато інноваційних управлінських рішень, нових освітніх технологій в економічну освіту.

Перспективи подальших досліджень полягають у вивченні перспективних напрямів використання досвіду профресійної підготовки фрахівців економічної галузі у вищих навчальних закладах Республіки Польща в Україні.

\section{БІБЛІОГРАФІЧНИЙ СПИСОК:}

1. Загородня А.А. Зміст професійної підготовки фахівців економічної галузі в Республіці Польщі. Проблеми економіки. 2015. № 4. С. 25-29. URL: http://nbuv.gov.ua/UJRN/Pekon_2015_4_4.

2. Про освіту / Верховна Рада України. Законодавство України. URL: https://zakon.rada.gov.ua/ go/1060-12.

3. Standardy kształcenia dla kierunku studiów: Ekonomia. URL: http://www.wpt. dracosk.pl/files/ dydaktyka/Standardy\%20Ekonomia.pdf.

4. Uniwersytetu Ekonomicznego w Krakowie. URL: http://nowa.uek.krakow.pl/pl/studenci/ wise-wydzialowaindywidualna-sciezka-edukacyjna.html. 